Creative commons User License: CC BY-NC-ND

Abstracted by: EBSCOhost, Electronic Journals Service (EJS),

Google Scholar, Directory of Open Access Journals (DOAJ),

Journal Seek, Scientific Commons,

Food and Agricultural Organization (FAO), and CABI
Journal of Agricultural Extension

Vol. 20 (1) June, 2016

ISSN(e): 24086851; ISSN(Print); $1119944 X$

http://journal.aesonnigeria.org

http://www.ajol.info/index.php/jae

Email: editorinchief@aesonnigeria.org

\title{
Performance of Improved Dairy Cattle Technologies Among Farmers in Northern Nigeria
}

Http://dx.doi.org/10.4314/iae.v20i1.1

\author{
Saleh, M.K. \\ Department of Agricultural Economics and Rural Sociology, \\ Ahmadu Bello University, Zaria \\ Email: quagyangsaleh@gmail.com or salequa@yahoo.com \\ Phone: 08123431446 / 08032849878
}

\section{Atala, T.K.}

Department of Agricultural Economics and Rural Sociology,

Ahmadu Bello University, Zaria

Email: atalatk@yahoo.com

Phone:08160088252

Omokore, D.F.

Department of Agricultural Economics and Rural Sociology,

Ahmadu Bello University, Zaria

Email: daveomokore@yahoo.com

Phone: 08036554983

\section{Ahmed, Ben}

Department of Agricultural Economics and Rural Sociology, Ahmadu Bello University, Zaria

Email: benujah@gmail.com

Phone: 08034501176

\section{Ali, F.S.}

Department of Geography, Ahmadu Bello University, Zaria

Email: yafandishetima@yahoo.com

Phone: 08054441729 / 07039862459

\section{Kajang, G.Y.}

Department of Agricultural Economics and Rural Sociology, Ahmadu Bello University, Zaria

E-mail: gykajang@gmail.com

Phone: 07036408453

\section{Abstract}

This study evaluated the performance of different dairy cattle technologies adopted by dairy farmers in 16 States of Northern Nigeria. Purposive sampling procedure was used to select the study area due to the presence of improved dairy farms in the area. Questionnaire was used to collect data from 61 registered improved dairy farmers in the area. The data collected were analyzed using descriptive statistics, F-test and gross margin analysis. The majority of improved dairy cattle farmers were in their middle age, majority of them (60\%) have university degrees, had annual income of about $\mathrm{N20}, 000,000.00$. It also 
Creative commons User License: CC BY-NC-ND

Abstracted by: EBSCOhost, Electronic Journals Service (EJS), Google Scholar, Directory of Open Access Journals (DOAJ),

Journal Seek, Scientific Commons,

Food and Agricultural Organization (FAO), and CABI
Journal of Agricultural Extension

Vol. 20 (1) June, 2016

ISSN(e): 24086851; ISSN(Print); 1119944X

http://journal.aesonnigeria.org

http://www.ajol.info/index.php/jae

Email: editorinchief@aesonnigeria.org

revealed low extension contact among dairy farmers. Dairy production was highly profitable with a gross margin of $\mathrm{A} 11$, 912.54, A6, 383.23 and N2, 547.99 per dairy cow for exotic, crossbred and Bunaji cattle. In terms of return per Naira invested, net gains of N10.20 was obtained for Frisian breed, crossbred (Friesian xBunaji) $\mathrm{N2.70}$ and Bunaij, was $\$ 1.50$. It was recommended that dairy farmers should be sensitized and encouraged to adopt exotic breed or crossbreed Bunaji cattle with Frisian bulls or artificially inseminate female Bunaji cattle. The study also recommended that extension workers should endeavour to link up farmers with sources of improved dairy cattle technologies.

Key words: Performance, dairy cattle, Northern Nigeria.

\section{Introduction}

Cattle are kept in most countries of the world for meat, dairy, hides and fibre production. FAO (2010) reported that dairy industry in Nigerian produces an estimate 450, 000 tons of milk per annum. This production has been found to be inadequate to satisfy the dairy demands of Nigerians (FAO, 2010) This is because the genotype of the African breeds of cattle can only produce an average milk of 1.27 litres per cow per day during the wet season and less than 0.36 during dry season (Yuan et al., 2010), whereas their counterparts in the European and American countries produce an average of 25 litres per day (Mallau-Aduli, et al., 2009). Consequently, protein deficiencies become a common phenomenon in Nigeria, especially among the poor segment of the society, which constituted majority of the population.

Local production of dairy supply in Nigeria is far below the annual demand which was estimated at 1.45 billion litres by 2010 (FAO, 2010), making milk consumption among Nigerians to be less than 10 litres per head, whereas the world standard was put at 40 litres per head Staal et al. (2008). Food and Agricultural Organisation (FAO, 2010) stated that Nigerian dairy sector is primarily conditioned by demand situation, not the supply constraint. Instead of taking advantage to invest in dairy farming, the gab is usually bridged by mass importation of dairy products into the country. In 2008 alone, Nigeria imported an average of 46, 853 metric tonnes of whole dried milk valued at $\$ 80,000,000$; milk skimmed dried at 29, 267 metric tonnes, valued at $\$ 13$, 827, 000 and milk whole evaporated was 8,053 metric tonnes, valued at $\$ 22,725,000$ (FAO, 2010) VS_GapAnalysisReport-Nigeria.pdf (application/pdf object). However, three dairy systems in Nigeria based on the use of farm inputs and outputs; they include pastoral, semi-intensive and intensive systems.

In pastoral system dominated milk production in Nigeria, it still supplies considerable amounts (over $70 \%$ ) of milk today (Olaloku and Debre, 1992). Semi- intensive system is common in peri-urban zones and it consist of dairy farms owned by business men, civil servants and private individuals who employ labour in the catering of their animals, with milk production as their 
Creative commons User License: CC BY-NC-ND

Abstracted by: EBSCOhost, Electronic Journals Service (EJS), Google Scholar, Directory of Open Access Journals (DOAJ),

Journal Seek, Scientific Commons,

Food and Agricultural Organization (FAO), and CABI
Journal of Agricultural Extension

Vol. 20 (1) June, 2016

ISSN(e): 24086851; ISSN(Print); 1119944X

http://journal.aesonnigeria.org

http://www.ajol.info/index.php/jae

Email: editorinchief@aesonnigeria.org

major objective of the venture (Diop and Mazouz, 1995). Dairying is done with some degree of intensification by a combination of grazing and concentratefeeding. Here, the use of graded cows or crossbreeding, usually between exotic bulls and local cows or through artificial insemination (AI) to upgrade local cows for better milk production (Bayemi et al., 2005). Intensive farms are usually owned by rich individuals or the government. Investments are made on buildings and machinery with the use of hired labour. These systems concentrate on the supply of milk in large towns and in most cases have one or more guaranteed delivery sources. There is a higher market orientation in this systems and more emphasis is laid on feeding and breeding management to assure optimal production (Diop and Mazouz, 1995). In both intensive and semi-intensive systems Al plays a major role in breeding, as it is cheaper and less cumbersome than maintaining an exotic bull.

Understanding the short supply of dairy products is a key to overcoming the problem. Thus, adoption of improved dairy cattle technologies - genetic improvement, feeds and animal healthcare into the system could be the possible solution. Therefore, this study investigated the productive performance of three breeds of dairy cattle, namely friesian, crossbreed(friesian $\times$ bunaji) and bunaji, adopted by dairy farmers, costs and return of sales of dairy products and constraints encountered by dairy cattle farmers.

\section{Methodology}

The study was carried out in 16 States of the north, namely; Adamawa, Bauchi, Borno, Gombe, Jigawa, Kaduna, Kano, Katsina, Kebbi, Kwara, Nassarawa, Niger, Plateau, Sokoto, Taraba and Yobe. Data collection took place between 2010 and 2011. Questionnaire technique was used for data collection. The researcher and trained enumerators were involved in the data collection which lasted for about 18 months from 61 improved dairy farmers. Purposive sampling procedure was used to select the respondents in the study area.

Performance analysis of adopted improved dairy technologies requires a sequence of logical steps. However, the most appropriate approach in agriculture literature (Greene, 2004) is informed by the types and characteristics of the data set. Data collected for the study were analysed using descriptive statistics, mainly frequencies and percentage, gross margin analysis and F-test. Descriptive statistics were used to describe socioeconomic characteristics of the respondents, breeds of dairy cattle kept, productive performance of the breeds and constraints of dairy farming. F-test was used to measure the differences of performance among the breeds of dairy cattle kept by dairy cattle farmers. Gross margin analysis was used to test and compare profitability of keeping the different breeds of dairy cattle by dairy farmers in the study area.

The Gross Margin (GM) analysis was used to measure profitability of the three breeds of dairy cattle. The GM is specified as follows: 
Creative commons User License: CC BY-NC-ND

Abstracted by: EBSCOhost, Electronic Journals Service (EJS), Google Scholar, Directory of Open Access Journals (DOAJ), Journal Seek, Scientific Commons,

Food and Agricultural Organization (FAO), and $C A B I$
Journal of Agricultural Extension Vol. 20 (1) June, 2016

ISSN(e): 24086851; ISSN(Print); $1119944 X$ http://journal.aesonnigeria.org http://www.ajol.info/index.php/jae Email: editorinchief@aesonnigeria.org

$\mathrm{GM}=\sum \mathrm{Q}_{\mathrm{y}} \mathrm{P}_{\mathrm{y}}-\sum_{i-1}^{n} \mathrm{X}_{\mathrm{i}} \mathrm{P}_{\mathrm{xi}}$

Where

$Q_{y}=$ Total milk output (litre)

$\mathrm{P}_{\mathrm{y}}=$ unit price of the milk products (Naira/litre)

$Q_{y} P_{y}=$ Total revenue derived from the sale of milk products (Naira)

$X_{i}=$ Quantity of the $i^{\text {th }}$ inputs used (value in Naira)

$P_{x i}=$ Price per unit of the $i^{\text {th }}$ input (Naira/litre)

$\Sigma=$ Summation of (input 1 to $n$ i.e. total variable cost) (Naira)

\section{Results and Discussion}

\section{Socio-economic Characteristics of the Respondents}

The findings in relation to the socio-economic characteristics (Table 1) of improved dairy farmers and institutional factors in the area suggest that $23 \%$ of the respondents were between 46 - 55 years old, $60 \%$ of them had University degrees and were primarily dairy cattle farmers. Majority $(60 \%)$ of them had between 5 and 15 years of herding experience. The distribution of annual income showed $34 \%$ of the respondents had less than N20, 000, 000. Extension services were generally low in the area with contacts of 3 to 4 visits per year. Water supply was quite accessible, $96 \%$ of the farmers live within the vicinity of all year round stream and $61 \%$ of them reported high market demand of dairy products. This finding agrees with that of Abubakar, S.Z. (2011) which reported that farmer's socio-economic background such as higher education, access to sources of portable water and social infrastructure were some of the necessities for adoption of improved dairy cattle technologies. 
Creative commons User License: CC BY-NC-ND

Abstracted by: EBSCOhost, Electronic Journals Service (EJS), Google Scholar, Directory of Open Access Journals (DOAJ),

Journal Seek, Scientific Commons,

Food and Agricultural Organization (FAO), and $\mathrm{CABI}$
Journal of Agricultural Extension

Vol. 20 (1) June, 2016

ISSN(e): 24086851; ISSN(Print); 1119944X http://journal.aesonnigeria.org http://www.ajol.info/index.php/jae Email: editorinchief@aesonnigeria.org

Table 1: Socio-economic characteristics of the dairy farmers

\begin{tabular}{|c|c|}
\hline 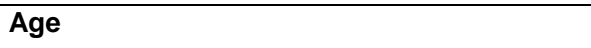 & Percent \\
\hline $16-25$ & 21 \\
\hline $26-35$ & 16 \\
\hline $36-45$ & 15 \\
\hline $46-55$ & 23 \\
\hline $56-65$ & 13 \\
\hline 66 and above & 12 \\
\hline $\begin{array}{l}\text { Educational status } \\
\text { No education } \\
\text { Adult education } \\
\text { Primary education } \\
\text { Secondary education } \\
\text { Tertiary education } \\
\text { University degree } \\
\text { Income ( } \mathbf{A}=\mathbf{0 0 0 , 0 0 0 )}\end{array}$ & $\begin{array}{c}8 \\
2 \\
4 \\
4 \\
22 \\
60\end{array}$ \\
\hline $\begin{array}{l}<10.0 \\
10.0-19.9 \\
20.0-29.9 \\
30.0-39.9 \\
40.0-49.9 \\
50.0-59.9 \\
60.0-69.9 \\
70.0-79.9 \\
80.0-89.9 \text { and above } \\
\text { Dairy farming experience (years) } \\
5 \text { and below }\end{array}$ & $\begin{array}{r}18 \\
16 \\
11 \\
10 \\
12 \\
4 \\
13 \\
10 \\
6 \\
\\
35\end{array}$ \\
\hline $6-10$ & 25 \\
\hline $11-15$ & 12 \\
\hline $16-20$ & 14 \\
\hline $\begin{array}{l}21-25 \\
26-30\end{array}$ & $\begin{array}{l}4 \\
2\end{array}$ \\
\hline $\begin{array}{l}31 \text { and above } \\
\text { Number of extension contacts (per year) } \\
\text { No contact } \\
3-4 \text { contacts }\end{array}$ & $\begin{array}{r}8 \\
15 \\
59\end{array}$ \\
\hline Don't know & 26 \\
\hline $\begin{array}{l}\text { Proximity to water } \\
\text { Located by all season stream } \\
\text { Located within vicinity of all season stream }\end{array}$ & $\begin{array}{l}52 \\
41\end{array}$ \\
\hline Less than one kilometer to all season stream & 5 \\
\hline One kilometer and above to all season stream & 2 \\
\hline \multicolumn{2}{|l|}{ Market demand } \\
\hline High demand & 61 \\
\hline Low demand & 39 \\
\hline
\end{tabular}

\section{Cattle breeds kept by the respondents}

Table 2 shows the number of improved cattle breeds kept by the respondents. The result showed that $65 \%$ of the cattle kept by respondents were friesian cattle, $21 \%$ were crossbred and $14 \%$ were indigenous breed, which were mainly the bunaji (white Fulani). On the average, $86 \%$ of the cattle in herds of the respondents were improved dairy cows, which means that commercial 
Creative commons User License: CC BY-NC-ND

Abstracted by: EBSCOhost, Electronic Journals Service (EJS), Google Scholar, Directory of Open Access Journals (DOAJ),

Journal Seek, Scientific Commons,

Food and Agricultural Organization (FAO), and CABI
Journal of Agricultural Extension Vol. 20 (1) June, 2016

ISSN(e): 24086851; ISSN(Print); 1119944X

http://journal.aesonnigeria.org

http://www.ajol.info/index.php/jae

Email: editorinchief@aesonnigeria.org

dairy farmers utilize hybrid cattle and improved dairy more than indigenous cows in their dairy industries. This finding is consistent with Ehocheet al. (2000) who reported that majority of cattle on dairy farms the developing countries, such as Nigeria are improved dairy cattle. Similar finding has been reported by Heinrichs et al. (2009) who stated that one of the excellent ways to improve herd productivity is to cross local cows to the exotic bulls and/or the introduction of semen from exotic breed into the female organ of local cow through artificial insemination.

Table 2: Dairy cattle of respondents by the breed

\begin{tabular}{lc}
\hline Breed & Percent \\
Friesian & 65.0 \\
Crossbreed & 21.0 \\
(Friesian×Bunaji) & \\
Bunaji & 14.0 \\
\hline & 100.0 \\
\hline
\end{tabular}

\section{Productive Performance of the Breeds}

Over the years, several local and improved breeds of dairy cattle have been identified and disseminated to farmers in the Northern States of Nigeria. The notable hybrid in the area is the Friesian and bunaji breeds. The friesian breed has been identified to have high milk output among the hybrid or exotic breeds, the same applies to bunaji among the indigenous breed of dairy cattle in Nigeria (Malau-Aduli et al., 2009). Table 3 compares the production performance of friesian, crossbreed and bunaji in the study area. The study revealed that friesian, crossbreed (Friesianxbunaji) and bunaji breeds produced an average of 30.15, 22.54 and 1.57 litres per day respectively. This result showed that one friesian dairy cow produces as much milk as one and half crossbreed (Friesianxbunaji) or three and half bunaji breeds. This finding agrees with that of Nicholson et al. (2000) who reported that there was a great difference in milk production between hybrid and indigenous dairy cattle in Coast Province of Kenya. Also on-station experiment carried out by NAPRI, Zaria gave a consistent average of 1.70 litres for bunaji breed, 27 litres for crossbreed and 35 litres for friesian dairy cattle (Ehoche, et al., 1999).

\section{Table 3: Milk yield of the of three breeds of dairy cattle (litre)}

\begin{tabular}{lc} 
Breed & Average Milk Yield of the Breed (Lit.) \\
Friesian & 30.15 \\
Crossbreed (Friesian×Bunaji) & 22.54 \\
Bunaji & 1.57 \\
\hline
\end{tabular}

\section{Analysis of Variation in Milk Yield of Cattle Breeds in the Study Area}

The study investigated milk yield of different breeds of dairy cattle breeds in the study area. The result obtained from the study revealed that the average milk yield of indigenous bunaji breed, crossbreed and friesian breed were 4.03 litres, 8.83 litres and 15.22 litres respectively (Table 4). The coefficients of 
Creative commons User License: CC BY-NC-ND

Abstracted by: EBSCOhost, Electronic Journals Service (EJS), Google Scholar, Directory of Open Access Journals (DOAJ),

Journal Seek, Scientific Commons,

Food and Agricultural Organization (FAO), and CABI
Journal of Agricultural Extension Vol. 20 (1) June, 2016

ISSN(e): 24086851; ISSN(Print); 1119944X

http://journal.aesonnigeria.org

http://www.ajol.info/index.php/jae

Email: editorinchief@aesonnigeria.org

variation were less than $50 \%$ across the three different breeds reflecting stability in the quantities of milk yields of the breeds in the study area. The minimum quantity of milk yield was 1.5, 2 and 4 litres per day for bunaji breed, crossbreed and friesian breed respectively while the maximum quantities were 15,25 and 60 litres respectively.

There is significant difference $(F=11.75 ; P \leq 0.05)$ between the quantities of milk yields of different breeds (Table 5). The significant difference in the quantity of milk yield may be attributed to genetic composition and to some extent management practices by dairy cattle farmers. This finding agrees with that of Nicholson et al. (2000) which reported differences in milk yields among exotic, cross-bred and indigenous cows in Coast Province of Kenya.

Table 4: Milk yield of three breeds of dairy cattle in the study area

\begin{tabular}{lccc}
\hline \multicolumn{1}{c}{ Estimates } & Bunaji & Crossbreed & Friesian \\
\hline Average & 4.03 & 8.83 & 15.22 \\
(litre/cow/day) & & & \\
St. Deviation & 3.03 & 8.00 & 13.30 \\
CV (\%) & 14.92 & 29.63 & 49.00 \\
Maximum & 1.50 & 2.00 & 4.00 \\
Minimum & 15.00 & 25.00 & 60.00 \\
\hline
\end{tabular}

Table 5: Differences in milk yield of breeds of dairy cattle in the study area

\begin{tabular}{llrll}
\hline Source of variation & SS & Df & MS & F \\
\hline $\begin{array}{l}\text { Between treatments } \\
\text { 0.000 }\end{array}$ & 133.95 & 2 & 66.98 & $11.75^{*}$ \\
Within groups & 336.30 & 59 & 5.70 & \\
\hline Total 470.25 61 & & & & \\
\hline
\end{tabular}

${ }^{*} \mathrm{P} \leq 0.05$

\section{Costs and Return Analysis of milk production among the Breeds}

The gross margin analysis (Table 6 ) shows feeds accounted for about $83 \%$ of the total variable cost incurred by farmers, labour accounted for about $16 \%$ and medication had the least. The largest percentage of $62.6 \%$ for feeding was spent on concentrates - groundnut/cotton cake. Corn bran and crop residues accounted for $16.9 \%$ of the expenses. The result showed that improved dairy farmers spent less on mineral licks and animal healthcare which together accounted for $1.7 \%$ of the variable cost. The high percent of feed cost indicates the importance of feed in dairy enterprise. It also constitutes reasonable indirect costs in labour requirement for grazing, milking, selling, dung and tick removal.

Table 6 shows the revenue from the sale of dairy products of the three breeds of cattle. The result indicated that $77 \%(\mathrm{~A} 139,713,846.15)$ of income realized from the sale of dairy products came from exotic cattle, $17 \%$ ( $\mathrm{N} 30$, 
Creative commons User License: CC BY-NC-ND

Abstracted by: EBSCOhost, Electronic Journals Service (EJS), Google Scholar, Directory of Open Access Journals (DOAJ),

Journal Seek, Scientific Commons,

Food and Agricultural Organization (FAO), and $C A B I$
Journal of Agricultural Extension

Vol. 20 (1) June, 2016

ISSN(e): 24086851; ISSN(Print); 1119944X

http://journal.aesonnigeria.org

http://www.ajol.info/index.php/jae

Email: editorinchief@aesonnigeria.org

$647,371.43)$ from crossbreed and 6\% ( $\mathrm{A} 10,134,366.67)$ from indigenous breeds. This finding suggests that dairy production for commercial purposes is mainly carried out by commercial dairy farms. The wide variation in the revenue among the three groups reflects the variation in genotype of the breeds. This is in agreement with the findings of Dwaipayan, B. (2008) which stated that productions for nationwide circulation and export are usually carried out by modern commercial dairy plants.

The gross margin analysis shows that milk production in the study area was highly profitable with gross margin of $\mathrm{A11}, 912.54$ for friesian, $\mathrm{N6}, 383.23$ for crosses and $\mathrm{A} 2,547.99$ for bunaji per head of cow. Returns for each breed showed that friesian dairy cattle were found to be most revenue yielding, followed by crossbreed and bunaji. In terms of the returns per Naira invested, in Frisian dairy cattle, for every one Naira invested on the management using improved dairy cattle technologies a net gain of $\mathrm{A} 10.20$ were obtained. In crossbreed (friesian $\times$ bunaji) dairy cattle, the returns per naira invested indicates that for every one naira invested, a net gain of N2.70 was obtained using improved dairy cattle management practices. Similarly, in bunaji, the result shows that for every one naira invested in the same practice a net gain of $\$ 1.50$ was realized. Similar result was obtained in Kenya, for instance, Kenyan Agricultural Research Institute (KARI) reported that 1 percent crossbred animals provided 40 percent milk demands of Kwale, Kili and Malindi districts (Nicholson et al., 2000). On the average, the number of exotic and cross-bred dairy cattle was reported to be 30 percent of total dairy animals in Kenya but provided 60 percent of the national milk demand in the country (Karanja, 2003). This is against 70 percent local breeds which produced less than 40 percent. It is clear that dairy-cattle farmers in Nigeria can possibly meet the dairy needs of the population if these technologies are well understood and extended.

These results indicate that intensification of adopting Frisian dairy cattle generated more returns to farmers than crossbred and bunaji dairy cattle in Northern Nigeria. Therefore, farmers should be encouraged to invest their resources in friesian dairy cattle using improved dairy cattle management technologies such as improved feeds, healthcare system and genetic improvement using natural crossbreeding or artificial insemination for increase milk productivity which in turn will increase the farmers' income and improve their level of living. 
Creative commons User License: CC BY-NC-ND

Abstracted by: EBSCOhost, Electronic Journals Service (EJS), Google Scholar, Directory of Open Access Journals (DOAJ),

Journal Seek, Scientific Commons,

Food and Agricultural Organization (FAO), and CABI
Journal of Agricultural Extension

Vol. 20 (1) June, 2016

ISSN(e): 24086851; ISSN(Print); $1119944 X$

http://journal.aesonnigeria.org

http://www.ajol.info/index.php/jae

Email: editorinchief@aesonnigeria.org

Table 6: Estimated cost and return per dairy cattle breed in Northern Nigeria

\begin{tabular}{|c|c|c|c|}
\hline Cost and Revenue & Friesian & Crossbreed & Bunaji \\
\hline Feeding calves & $407,845.58$ & $273,565.00$ & $133,589.42$ \\
\hline Grazing & $531,898.62$ & $356,774.35$ & $174,222.87$ \\
\hline Milking & $212,589.51$ & $142,595.75$ & $70,663.48$ \\
\hline Removal of dung & $492,133.67$ & $330,101.76$ & $161,197.90$ \\
\hline Removal of ticks & $318,119.56$ & $213,380.70$ & $104,199.75$ \\
\hline Selling & $64,104.32$ & $42,998.38$ & 996.35 \\
\hline Cost of corn bran & $2,098,456.23$ & $1,407,552.74$ & $687,347.28$ \\
\hline Cost of cotton seed cake & $1,525,792.86$ & $1,023,435.18$ & $499,771.96$ \\
\hline Cost of groundnut cake & $6,255,839.53$ & $4,196,143.79$ & $2,049,094.10$ \\
\hline Cost of mineral licks & $140,519.07$ & $94,254.05$ & $46,026.88$ \\
\hline Cost of sunseed cake & $392,387.03$ & $263,196.07$ & $128,525.99$ \\
\hline Cost of Medication & 550.47 & 369.23 & 180.30 \\
\hline $\begin{array}{l}\text { Total Variable Costs } \\
\text { (TVC) (N) }\end{array}$ & $12,440,236.44$ & $8,344,366.99$ & $4,105,816.29$ \\
\hline Average yield (lit./cow) & 15.22 & 8.83 & 4.03 \\
\hline Average price (Naira/lit) & 175.00 & 175.00 & 175.00 \\
\hline Gross Revenue (Naira/lit.) & $139,713,846.15$ & $30,647,371.43$ & $10,134,366.67$ \\
\hline Gross Margin/head & $11,912.54$ & $6,383.23$ & $2,547.99$ \\
\hline Return per Naira invested & 11.20 & 3.70 & 2.50 \\
\hline
\end{tabular}

\section{Constraints to Dairy Cattle Farming in the Area}

The adoption of dairy production technology in the study area is not without problems. The major problems observed from the study were ranked and presented in Table 7. poor extension services, poor power supply, inadequate/lack of veterinary services, high costs of inputs, Low product prices, diseases and pests, lack of modern storage facilities, inadequate credit facilities and poor transportation facilities were the most prominent problems militating against dairy farming in the study area.

Table 7: Constraints faced by dairy farmers in the study area

\begin{tabular}{lc}
\hline Constraints & Ranking \\
\hline Poor extension services & 1 \\
Poor power supply & 2 \\
Inadequate/lack of veterinary services & 3 \\
High cost of inputs & 4 \\
Low output prices & 5 \\
Storage Problems & 6 \\
Inadequate Credit Facilities & 7 \\
Transportation Problems & 8 \\
Poor soil to grow fodder crops & 9 \\
Diseases and pests & 10 \\
Problems of feeding the animals in dry season & 11 \\
Input Scarcity & 12 \\
\hline
\end{tabular}




\section{Conclusion and Recommendations}

Therewere significant differences in the quantity of milk yield among the three groups of dairy cattle. Feed and labour accounted for greater expenditureof the total variable costs in dairy production and process. Dairy farming was still highly profitable venture in the area. However, farmers encountered problems of low prices for their products, poor power supply and inadequate extension contact.

To overcome the animal protein shortage in Nigeria, dairy farmers should be encouraged to used Frisian breed and crossbreed in dairy industry.

Dairy farmers should be sensitized and encouraged to adopt the use of improved quality feeds and veterinary prompt veterinary services for healthy and improved dairy and dairy products.

Poor extension services should be improved by training more extension workers specifically for livestock services.

Poor power supply, high costs of inputs and veterinary services should be addressed at the family farm level.

\section{References}

Abubakar, S.Z. (2011). "Towards Invigorating Livestock Extension Strategy in North-west Geo-political Zone of Nigeria". An Invited Paper Presented at REFILS Workshop, Institute for Agricultural Research (IAR), Ahmadu Bello University, 24 - 25 February, 2011, Zaria.

Bayemi, P.H., Bryant, M.J., Pingpoh, D., Imele, H., Mbanya. J., Tanya, V., Cavestany, D., Awoh, J., Ngoucheme, A., Sali, D., Ekoue, F., Njakoi, H. and Webb, E.C. (2005).Participatory Rural Appraisal of Dairy Farms in the North West Province of Cameroon. Livestock Research for Rural Development. Vol. 17, Art. \# 59. Retrieved December 13, 2006, from http://www.cipav.org.co/lrrd//rrd17/6/baye17059.htm

Diop, P.E.H. and Mazouz, A. (1995). Production laitière en Afrique au sud du Sahara : problématique et stratégie. In Reproduction et production laitière. Actualité Scientifique. Universités Francophones. pp 19 - 26 http://www.bibliotheque.refer.org/livre68//6800.pdf

Dwaipayan, B. (2008). 'An Assessment of Risk Attitude of Dairy Farmers in Uttaranchal, India'. Paper Presented at the International association of agricultural Economists Conference, Gold Coast, Australia, August, 2008.

Ehoche, O.W.; Barje, P.P.; Chiezey,N.P.; Adeyinka, I.A,; Okaiyeto, P.O.; Rekwot, P. I.; Lufadeju, O.P.; Akinpelumi, R.O.; Oyedipe, E.O. and Agyemang, K. (1999). "Effect of feed supplementation and Helmut 
control on the performance of indigenous cattle under small holder peri-urban dairy production system," NAPRI/ABU, Zaria". Journal of Agriculture and Social Research (JASR), 8(2):150

Food and Agriculture Organization (2010). Production Year Book, UN Publication Rome. (PVS_GapAnalysisReport-

Nigeria.pdf(application/pdf object) (accessed on 23/1/2013).

Greene, G. (2004) Incorporating Nutritional Goals into International Agricultural Research-An ILCA Perspective. In: Pinstrup-Andersen P.; Berg, A. and Forman M. (eds), International Agricultural Research and Human Nutrition. IFPRI (International Food Policy Research Institute), Washington, DC, USA, pp. 141-152.

Heinrichs, A.J.; Hutchinson, L.J. and Ishler, V.A. (2009). Management of Dairy heifers: Extension Circular 383; Pennsylvania State University, USA, $543-557 \mathrm{pp}$.

Karanja, A.M. (2003). The Dairy Industry in Kenya: The Post-Liberalization, Tegemeo Agricultural Monitoring and Policy Analysis (TAMPA II) Project, United State Agency for International Development (USAID), Nairobi, Kenya.

Malau-Aduli, A.E.O.; Dim, N.I.; Abubakar, B.Y.; Ehoche, O.W.; Lufadeju, E.A. and Olaoshebikan, Y.R. (2009). "Dairy Performance of Friesian-Bunaji Crosses and their Growth to Yearling Age." Seminar paper presented at the National Animal Production Research Institute (NAPRI), Shika, Nigeria. Feb. 18 2009.

Nicholson, C.F., Thornton, P.K., Mohammed, L,, Muinga, R.W., Mwomachi, D.M., Elbasha, E.H., Staal, S.J. and Thorpe, W. (2000). Small holder Dairy Technology in Coastal Kenya:An Adoption and Impact Study. ILRI (International Livestock Research Institute), Nairobi, Kenya, 5460pp.

Olaloku, E.A. and Debre, S. (1992). Research priorities for the development ofappropriate feeding systems for dairy production in sub-Saharan Africa, In: Stares J, Said A and Kategile: The complementarity of Feed Resources for Animal Production in Africa. Proceedings of the Joint Feed Resources Networks workshop held in Gaborone, Botswana 4-8 march 1991. http://www.fao.org/Wairdocs/ILRI/x5519B/x5519b1j.htm

Staal, J.B., van Eijsden-Besseling M.D., van Attekum, A. and de Bie R.A. (2008). No Difference between Postural Exercises and Strength and Fitness Exercises for Early, Non-specific, Work-related upper limb Disorders in Visual display unit workers: A Randomised Trial. Australian Journal of Physiotherapy 54(2):95-101. 
Creative commons User License: CC BY-NC-ND

Abstracted by: EBSCOhost, Electronic Journals Service (EJS), Google Scholar, Directory of Open Access Journals (DOAJ), Journal Seek, Scientific Commons,

Food and Agricultural Organization (FAO), and CABI
Journal of Agricultural Extension

Vol. 20 (1) June, 2016

ISSN(e): 24086851; ISSN(Print); 1119944X

http://journal.aesonnigeria.org

http://www.ajol.info/index.php/jae

Email: editorinchief@aesonnigeria.org

Yuan, X., Lee, H.S. and Kim, S.Y. (2010). Present and Future of Internet Banking in China. Journal of Internet Banking and Commerce. 15(1): 678-683. 